\title{
Expert System to Diagnose Eye Disease Due to Frequently Using Computer with Bayes Theorem Method
}

\author{
${ }^{1}$ Taozara Laia, ${ }^{2}$ Penda Sudarto Hasugian
}

1,2Informatics Engineering, STMIK Pelita Nusantara, Sumatera Utara, Indonesia

\section{Article Info}

\section{Article history:}

Received 09/12/2021

Revised 12/12/2021

Accepted 11/01/2022

Available online 30/01/2022

\section{Keywords:}

Expert System

Eye Disease

Bayes Theorem

\begin{abstract}
Eye disease due to frequent use of computers is one of the dangerous diseases in health because if not treated quickly it will result in blindness. These eye diseases can be diagnosed through the symptoms that arise in humans or through their clinical picture, through these symptoms an expert system can be made to make a diagnosis. An expert system is a system that seeks to adopt human knowledge to a computer that is built to solve problems like an expert. The expert system made in carrying out the diagnosis uses the Bayes theorem method to calculate the probability of an event occurring based on the influence obtained from the results of observations and experts. The system was built using PHP and MySQL programming as a database. The method used for tracing is Bayes' theorem. While the results of the diagnosis will inform about the results of the diagnosis containing a list of symptoms entered, information on the results of the rules regarding the eye disease suffered and information about possible treatments that can be carried out as well as treatment solutions.
\end{abstract}

This is an open access article under the CC BY-NC license.

\section{Corresponding Author:}

Taozara Laial,

Informatics Engineering,

STMIK Pelita Nusantara Medan,

Jl. Iskandar Muda No. 1 Medan, 20154, Indonesia.

Email: taozaralaia2903@gmail.com

\section{Introduction}

Along with the development of computer information technology today makes many human activities depend on computer information technology. The current era of technology has a fairly broad impact in various aspects of life, including in human activities every day. The world is now approaching or has entered the era of the 4th industrial revolution (Industry 4.0) where the internet and information and communication technology are being integrated into manufacturing equipment and create connectivity or communication that may never have been seen before. Humans are on the verge of a fundamental technological revolution that will change the way we live, work and relate to one another. In the era of the industrial revolution 4.0, many human activities were replaced by machines or robots, this resulted in all human activities being converted from manual to computerization so that the required human power was reduced. Humans nowadays use computer information technology almost every day, because they use this computer too often, it affects or causes disease in the human eye.

Eye disease due to frequent use of computers (Computer Vision Syndrome) is one of the eye diseases caused by staring at a computer screen for too long. A common symptom that usually accompanies CVS is tiredness or soreness in the eyes. Even in some cases this disease is accompanied by headaches, neck, shoulders and back pain. The majority in Indonesia $50-90 \%$ who often use computers suffer from this disease(Priliandita, 2015). Eye disease due to frequent use of computers is 
one of the eye diseases for humans because if it is not treated quickly it can lead to blindness for the sufferer. This disease can affect anyone regardless of age, gender, occupation and region and is not clearly visible but can be a big problem if not followed up or diagnosed. For this reason, it is necessary to create an expert system to diagnose the disease, where for diagnosing eye diseases in community clinics sometimes experience long queues due to limited doctors or often out of town. Thus, for the smooth operation of diagnosing eye diseases, it is necessary to create an expert system using the Bayes theorem method to assist in the management of patients.

Bayes theorem is a method used to calculate the probability of an event occurring based on the influence obtained from observations. Bayes' theorem allows one to influence his belief in knowing a parameter after the data is obtained. Where is the statistical approach in calculating the trend-off between different decisions, using probability (Syahputra, Dahria, \& Putri, 2017).

This study aims to find out how to apply the Bayes theorem method in the application of an expert system for diagnosing eye diseases due to frequent use of computers, and how to design and build an expert system application for diagnosing eye diseases due to frequent use of computers in order to help people make independent diagnoses and how to obtain diagnostic results with the application of Bayes' theorem method.

This study uses several library sources in the form of research journals related to the research topic that will be discussed in this study. The literature review is a research entitled Design of an Expert System for Diagnosing Eye Diseases Using Bayes' Theorem Method. This study diagnosed five types of eye diseases, namely cataract, keratitis, hordiolom, conjunctiva, and glaucoma with twentytwo types of symptoms (Sagat \& Purnomo, 2021). Then in the research entitled Expert System Detection of Eye Refractive Diseases Using Web-Based Bayes Theorem Method. This study focuses on diagnosing refractive errors of the eye by using a programming language such as PHP and MySQL database and using Bayes' theorem method. The diagnosed diseases consisted of myopia, hypermetropia, astigmatism, and presbyopia with twenty types of symptoms (Qamaruzzaman, 2016). The next research journal entitled Expert System To Diagnose Eye Diseases in Humans Using Bayes Theorem. The eye diseases diagnosed were myopia, hypermetropia, astigmatism, presbyopia, cataracts, conjunctivitis, keratitis, glaucoma, blepharitis, diabetic retinopathy, hypertensive retinopathy, chalazion, hordeolum, and pterygium. In testing using twenty samples of disease symptom data, it shows that the application produces an accuracy value of $90 \%$ (Siregar, 2017). Next in the study entitled Expert System for Diagnosing Eye Diseases Based on Android, the eye diseases diagnosed were conjunctivitis, blepharitis, hordeolum, acute glaucoma, scleritis, iritis, chalazion, keratitis and cataracts which consisted of sixteen types of disease symptoms (Ramadhan, Kom, Pane, \& Kom, 2018). Next is the Expert System for Diagnosing Immune Dermatitis Using the Bayes Theorem Method. In this study, the object of research is about immune dermatitis in humans with eczema, psoriasis and atopic immune dermatitis which consists of ten symptoms of the disease(Ramadhan, 2018). The next research is entitled Expert System Diagnosing Herpes Zoster Disease Using Bayes Theorem Method. In this study, the diagnosed herpes zoster was divided into ophthalmic herpes zoster, cervical herpes zoster, thoracic herpes zoster, lumbar herpes zoster, sacral herpes zoster and otic herpes zoster (Sihotang, Panggabean, \& Zebua, 2018). The next research is the application of the Bayes theorem method in an expert system for diagnosing gastric disease. In this study, diagnosing gastric diseases consisting of gastritis, dyspepsia, and gastro-exofagus repluksides with twenty types of symptoms (Murni \& Riandari, 2018). Next is the Expert System for Diagnosing Allergies Using the Bayes Theorem Method. This research uses PHP programming language with MySQL database and the method used is Bayes theorem (Kurniawan, 2017). The next research journal is the Expert System for Diagnosing Anemia Using Bayes Theorem. This study diagnoses three types of anemia, namely aplastic anemia, substance deficiency and chronic anemia and the symptoms of the disease consist of fifty symptomatic data using the Bayes theorem method (Sulardi \& Witanti, 2020). 


\section{Method}

\subsection{Research Framework}

This research method consists of a research framework, which is a description of how it works and the steps for conducting research, while the framework of this research includes:

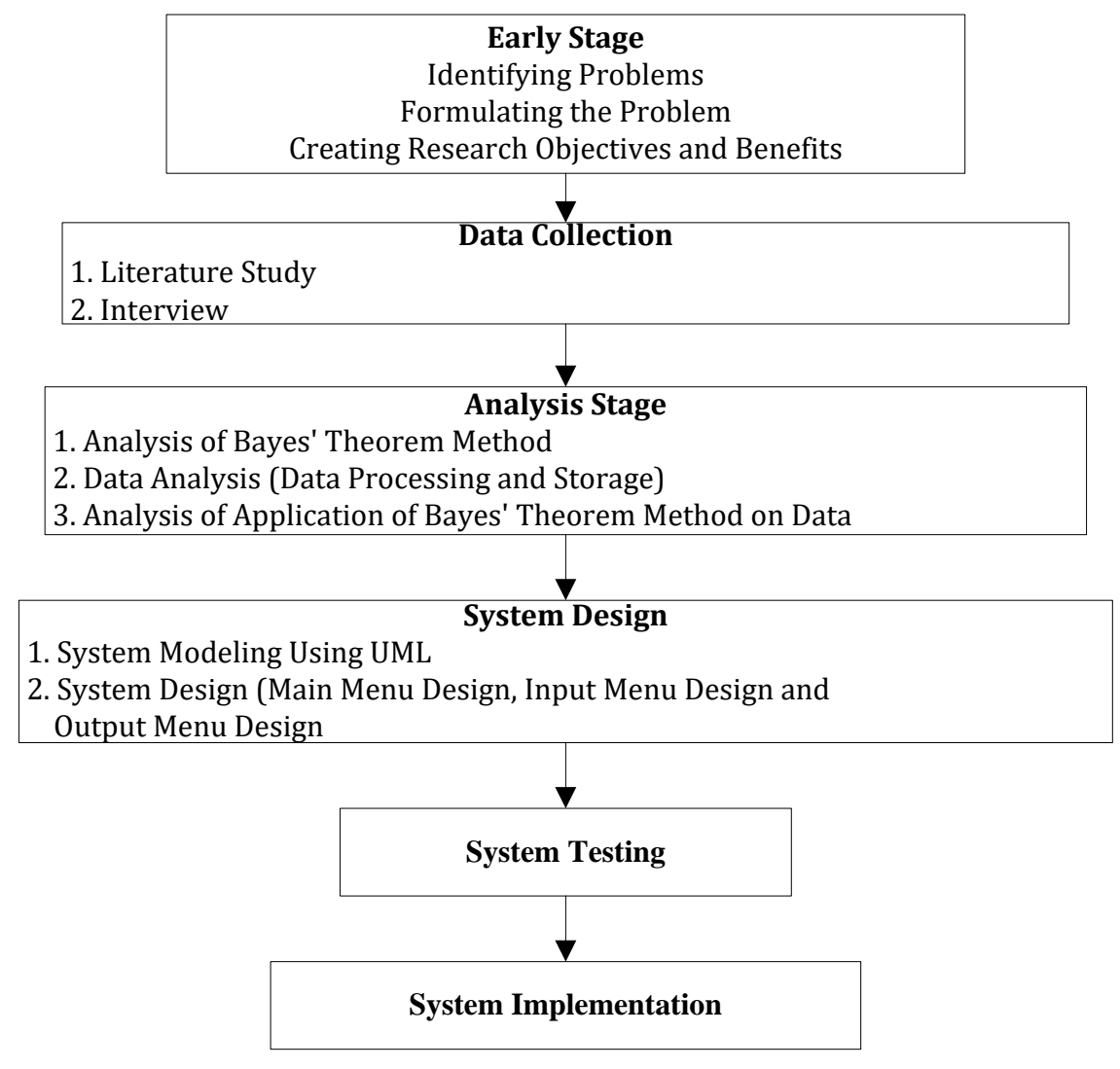

Figure 1. Research Framework

\subsection{Description of the Framework}

The description of the framework is a further explanation regarding the description of the process of the research framework carried out, along with the explanation:

a. Early Stage

1). Identifying Problems

Searching, finding, collecting, researching, registering, recording data and information needed in building expert system applications to diagnose eye diseases due to frequent use of computers using the Bayes theorem method.

2). Formulating the Problem

Formulating problems that are being faced by the wider community so far in diagnosing eye diseases due to frequent use of computers so that the system built will be useful.

3). Creating Study Goals and Benefits

Determine what is the purpose of building an expert system for diagnosing eye diseases due to frequent use of computers and its benefits for the wider community.

b. Data Collection

1). Literature Study 
Looking for theoretical references that are relevant to the case or problem found in accordance with the research title. These references are obtained from books, journals, research report articles, and websites on the internet.

2). Interview

Direct interviews with respondents, the respondents referred to in this study were in the form of eye disease specialist dr. Nurlela Kamaruddin, $\operatorname{Sp} . \mathrm{M}(\mathrm{K})$ at the inpatient primary clinic "Zaskia Husada" on Jln. M.H. Thamrin, Lubuk Pakam, Kab. Deli Serdang, North Sumatra, to obtain data on the types of eye diseases caused by frequent computer use and their symptoms as well as solutions for treating eye diseases caused by frequent computer useAnalysis Stage

c. Analysis Stage

1). Analysis Bayes Theorem

The research process in which the data that has been collected is managed to be processed in order to answer the problem formulation in expert system research on diagnosing eye diseases due to frequent use of computers using the Bayes theorem method.

2). Data Analysis (Data Processing and Storage)

To process data into new information so that the characteristics of the data become easier to understand and useful for problem solving, especially those related to research on expert system applications for diagnosing eye diseases due to frequent use of computers using the Bayes theorem method.

3). Analysis of Application of Bayes' Theorem Method on Data

To describe the initial design to be used as a reference at the design stage.

d. System Planningg

1). System Modeling Using UML

Modeling or describing existing problems and the relationship between components, variables, and parameters in building an expert system application for diagnosing eye diseases due to frequent use of computers using the Bayes theorem method. In modeling this system using UML (Unified Modeling Language) in the form of use case diagrams, activity diagrams and class diagrams.

2). System Design

System design and implementation, describes how a system is formed which can be in the form of drawing, planning and sketching in building an expert system application for diagnosing eye diseases due to frequent use of computers using the Bayes theorem method.

e. System Testing

Test the functionality of all systems and error handling on the system that is made as expected. Testing of this system will be first carried out on the localhost server, for example: http://localhost/diagnosa-disease-eyes/.

f. System Implementation

The stage of putting the system so that it is ready for operation and can be seen as an effort to realize the system that has been designed.

\section{Result and Discussion}

In designing this expert system by taking sources from experts or doctors, books and journals. This web-based design is useful for diagnosing eye diseases due to frequent computer using bayes theorem method.

a. Type of Disease

TABLE 1

Eye Disease Due To Frequent Use Of Computers

\begin{tabular}{|c|c|c|}
\hline Code & Disease Name & Definition of Disease \\
\hline P1 & $\begin{array}{l}\text { Blurred Vision } \\
\text { (Cataract) }\end{array}$ & Loss of visual acuity and the inability to see objects in detail \\
\hline P2 & $\begin{array}{l}\text { Double Visible Vision } \\
\text { (Diplopia) }\end{array}$ & $\begin{array}{l}\text { Double vision (diplopia) is a visual disorder in which the sufferer will see two } \\
\text { objects from one object that is close together. vision where the patient will see two } \\
\text { objects from one object that is close together. }\end{array}$ \\
\hline P3 & Dry Eyes or Red Eyes & A condition when the eye does not get adequate lubrication from tears, so this \\
\hline
\end{tabular}




\begin{tabular}{|c|c|c|}
\hline Code & Disease Name & Definition of Disease \\
\hline & $\begin{array}{l}\text { (Keratoco-njunctivitis } \\
\text { Sicca) }\end{array}$ & $\begin{array}{l}\text { condition makes the eye unable to remove dust or foreign objects that irritate the } \\
\text { eye }\end{array}$ \\
\hline P4 & Eye Irritation (Uveitis) & $\begin{array}{l}\text { A condition characterized by swelling in the middle layer of the eye wall tissue } \\
\text { (uvea). }\end{array}$ \\
\hline P5 & $\begin{array}{l}\text { Sensitivity to Light } \\
\text { (Photophobia) }\end{array}$ & $\begin{array}{l}\text { Photophobia is not a psychological disorder/fear of light, but a type of disease that } \\
\text { makes the eyes glare, even headaches and nausea caused by staring at the computer } \\
\text { screen for too long. }\end{array}$ \\
\hline P6 & $\begin{array}{l}\text { Myopic Eyes (Myopia } \\
\text { and Hypermetropia) }\end{array}$ & $\begin{array}{l}\text { Types of diseases or visual disturbances in the eyes due to frequent use of } \\
\text { computers, namely the eyes can become farsighted, both nearsighted (myopia) and } \\
\text { farsighted (hypermetropia). }\end{array}$ \\
\hline
\end{tabular}

b. Solution and Treatment

TABLE 2

Solution And Treatment

\begin{tabular}{|c|c|c|}
\hline Code & Disease Name & Solution and Treatment \\
\hline P1 & $\begin{array}{l}\text { Blurred Vision } \\
\text { (Cataract) }\end{array}$ & $\begin{array}{l}\text { Perform regular and regular eye examinations, use blue light glasses when using } \\
\text { a computer such as Eyezen and Blue UV Capture, use sunglasses or Transition } \\
\text { lenses when using a computer during the day, Consumption of Vitamin C, E, Zinc } \\
\text { and Omega } 3 \text { Fatty Acids. }\end{array}$ \\
\hline P2 & $\begin{array}{l}\text { Double Visible } \\
\text { Vision } \\
\text { (Diplopia) }\end{array}$ & $\begin{array}{l}\text { Use special corrective lenses that can correct vision problems, surgery, and non- } \\
\text { surgical therapies that align the eyes and stimulate vision pathways to the brain } \\
\text { that are not working properly. Functions to align the eyes and stimulate the } \\
\text { pathways of vision to the brain that are not working properly. }\end{array}$ \\
\hline P3 & $\begin{array}{l}\text { Dry Eyes or Red } \\
\text { Eyes (Keratoco- } \\
\text { njunctivitis } \\
\text { Sicca) }\end{array}$ & $\begin{array}{l}\text { Use eye lubricants or often referred to as artificial tears in the form of eye drops, } \\
\text { gels, or ointments and avoid using eye makeup, adjust the length of work in } \\
\text { front of the computer, maintain eye hygiene by using warm compresses on the } \\
\text { glands around the eyes, and consume a lot of omega } 3 \text { fatty acids such as } \\
\text { mackerel, tuna, sardines and salmon. }\end{array}$ \\
\hline $\mathrm{P} 4$ & $\begin{array}{l}\text { Eye Irritation } \\
\text { (Uveitis) }\end{array}$ & $\begin{array}{l}\text { Treatment of uveitas is to reduce inflammation in the eye, it is recommended to } \\
\text { use corticosteroids, antibiotics or antivirals, and immunosuppressive drugs. }\end{array}$ \\
\hline P5 & $\begin{array}{l}\text { Sensitivity to } \\
\text { Light } \\
\text { (Photophobia) }\end{array}$ & $\begin{array}{l}\text { Get plenty of rest by reducing activity in front of a computer monitor, using eye } \\
\text { drops, anti-inflammatory drugs, and performing surgery to remove excess blood } \\
\text { and reduce pressure on the brain for subarachnoid hemorrhage. }\end{array}$ \\
\hline P6 & $\begin{array}{l}\text { Myopic Eyes } \\
\text { (Myopia and } \\
\text { Hypermetropia) }\end{array}$ & $\begin{array}{l}\text { Eat healthy foods, reduce activity in front of the computer at night, use glasses } \\
\text { or contact lenses, and if it is too severe, perform laser surgery in the form of } \\
\text { Laser-assisted in situ keratomileusis (LASIK), Laser-assisted subepithelial } \\
\text { keratectomy (LASEK) and Photorefractive keratectomy (PRK). }\end{array}$ \\
\hline
\end{tabular}

c. Disease Symptoms

TABLE 3

DiSEASE SYMPTOMS

\begin{tabular}{|c|c|c|}
\hline Code & Symptoms Disease & Weight \\
\hline G001 & Vision starts to get blurry & 1.0 \\
\hline G002 & Eyes sensitive to light & 0.9 \\
\hline G003 & Vision sometimes starts to become double. & 0.8 \\
\hline G004 & Eyesight begins to decline at night when using a computer. & 0.9 \\
\hline G005 & If you use a computer, your vision seems to be visible or starts to turn yellow. & 1.0 \\
\hline G006 & $\begin{array}{l}\text { Wearing glasses often changes the focal point and the glasses don't feel right and want to replace } \\
\text { them with new ones. }\end{array}$ & 0.6 \\
\hline G007 & Head hurts & 0.7 \\
\hline G008 & Pain in the temple of the eye & 0.9 \\
\hline G009 & Stomach feels nauseous if you use the computer for too long at night. & 1.0 \\
\hline G010 & Eyes begin to weaken to use the computer for too long. & 1.0 \\
\hline G011 & $\begin{array}{l}\text { The face, legs, and arms that suddenly feel weak due to the eyes starting to become weak due to } \\
\text { frequent use of the computer. }\end{array}$ & 0.5 \\
\hline G012 & Drooping eyelids & 1.0 \\
\hline G013 & The eyes begin to experience fireflies, dizziness and loss of balance of vision. & 0.8 \\
\hline G014 & The eyes look very red. & 0.9 \\
\hline G015 & Eyes feel hot if you stare at the computer monitor for too long. & 1.0 \\
\hline G016 & Watery eyes due to the body's response to irritation in dry eyes & 0.9 \\
\hline
\end{tabular}




\begin{tabular}{llc}
\hline Code & \multicolumn{1}{c}{ Symptoms Disease } & Weight \\
\hline G017 & If you use the computer too often during the day, your eyes are sensitive to sunlight. & 0.9 \\
G018 & $\begin{array}{l}\text { It is difficult to open your eyes when you wake up, because the upper and lower eyelids stick } \\
\text { together. }\end{array}$ & 0.6 \\
G019 & There is mucus in or around the eyes. & 1.0 \\
G020 & There are difficulties when wearing contact lenses or using a computer at night with low light & 0.8 \\
G021 & The eyes feel tired, tired, tired and even unable to linger looking at the computer monitor screen. & 1.0 \\
G022 & Experiencing pain in the eyes and the eyes release very sore water. & 0.9 \\
G023 & Blurred vision due to red eyes & 0.9 \\
G024 & There are black spots that appear in the field of view on the computer monitor screen & 0.9 \\
G025 & The eyes have decreased function to see and stare at the monitor screen for too long & 0.6 \\
G026 & Inflammation of the uvea (middle layer of the eye) & 1.0 \\
G027 & Inflammation of the cornea of the eye & 0.8 \\
G028 & The membranes that line the whites of the eyes and eyelids begin to blacken or appear gray. & 0.7 \\
G029 & Having an abrasion on the cornea of the eye is a scratch on the surface of the cornea of the eye. & 1.0 \\
G030 & The clouding of the eye lens and the eye often twitch & 0.8 \\
G031 & Seems out of focus when looking at objects too close & 0.8 \\
G032 & The eyes start to get red, tired and feel sore because the eyes work too much. & 0.9 \\
G033 & Have to squint to see something to make it clearer to see. & 0.4 \\
G034 & Often winks & 0.3 \\
G035 & Often squints eyes when looking at distant objects & 0.9 \\
G036 & Eyes feel tense, sore and burning if you use the computer for too long & 0.4 \\
G037 & The eyes feel tired and tired and the head hurts after using the computer. & 1.0 \\
G038 & Often rubs eyes & 0.9 \\
G039 & Seems oblivious to the presence of objects too far away. & 0.8 \\
\hline
\end{tabular}

d. Rule Base

TABLE 4

RULE BASE

\begin{tabular}{|c|c|}
\hline Rule & Knowledge Base \\
\hline Rule & $\begin{array}{l}\text { IF Vision begins to blur (G001) AND Eyes are sensitive to light (G002) AND Sometimes vision } \\
\text { begins to double (G003) AND Eyesight begins to decline at night when using a computer (G004) }\end{array}$ \\
\hline 1 & $\begin{array}{l}\text { AND If using a computer, vision feels Visible or starts to yellow (G005) AND Wearing glasses } \\
\text { often changes the focus point and the glasses don't feel right and wants to replace them with new } \\
\text { ones (G006) THEN P1-Blurred Vision (Cataract). }\end{array}$ \\
\hline $\begin{array}{c}\text { Rule } \\
2\end{array}$ & $\begin{array}{l}\text { IF Head hurts (G007) AND Pain in the temples (G008) AND Stomach feels nauseous when using } \\
\text { the computer for too long at night (G009) AND Eyes start to weaken to use the computer for too } \\
\text { long (G010) AND Face, legs and arms who suddenly felt weak due to weak eyes due to frequent } \\
\text { use of the computer G011) AND drooping eyelids (G012) AND eyes began to experience } \\
\text { lightheadedness, dizziness and loss of balance of vision (G013) THEN P2-Double Vision } \\
\text { (Diplopia) }\end{array}$ \\
\hline $\begin{array}{c}\text { Rule } \\
3\end{array}$ & $\begin{array}{l}\text { IF Eyes look very red (G014) AND Your eyes feel hot when you stare at the computer monitor for } \\
\text { too long (G015) AND Watery eyes due to the body's response to irritation in dry eyes (G016) } \\
\text { AND If you use the computer too often during the day, your eyes are sensitive to light the sun } \\
\text { (G017) AND Difficulty opening the eyes when waking up, because the upper and lower eyelids } \\
\text { stick together (G018) AND There is mucus in or around the eyes (G019) AND There is difficulty } \\
\text { when wearing contact lenses or using a computer at night with poor lighting (G020) AND Eyes } \\
\text { feel tired, tired, tired and can no longer even stare at the computer monitor screen (G021) THEN } \\
\text { P3-Dry Eyes or Red Eyes (Keratoconjunctivitis Sicca) }\end{array}$ \\
\hline $\begin{array}{c}\text { Rule } \\
4\end{array}$ & $\begin{array}{l}\text { IF Experiencing pain in the eyes and the eyes are very painful (G022) AND Blurred vision due to } \\
\text { red eyes (G023) AND There are black spots that appear in the field of view on the computer } \\
\text { monitor screen (G024) AND The eyes have decreased function to see and staring at the monitor } \\
\text { screen for too long (G025) THEN P4-Eye Irritation (Uveitis) }\end{array}$ \\
\hline $\begin{array}{c}\text { Rule } \\
5\end{array}$ & $\begin{array}{l}\text { IF There is inflammation of the uvea (middle layer of the eye) (G026) AND There is inflammation } \\
\text { of the cornea of the eye (G027) AND The membrane that covers the whites of the eyes and the } \\
\text { eyelids begins to darken or looks gray (G028) AND There is an abrasion on the cornea of the eye, } \\
\text { namely the presence of scratch on the surface of the cornea (G029) AND Clouding of the lens of } \\
\text { the eye and frequent twitching of the eye (G030) THEN P5 - Sensitivity to Light (Photophobia) }\end{array}$ \\
\hline $\begin{array}{l}\text { Rule } \\
6\end{array}$ & $\begin{array}{l}\text { IF Doesn't seem to focus when looking at objects that are too close (G031) AND Eyes start to get } \\
\text { red, tired and feel sore due to overwork or using the computer too often (G032) AND Have to }\end{array}$ \\
\hline
\end{tabular}




\begin{tabular}{ll} 
Rule & Knowledge Base \\
\hline squint to see things to make things clearer to see (G033) AND Often blinks (G034) AND Squints \\
frequently when looking at distant objects (G035) AND Eyes feel tense, sore and burning when \\
using the computer for too long (G036) AND Eyes feel tired and tired and head hurts after using \\
the computer computer (G037) AND rubs eyes frequently (G038) AND Seems unaware of objects \\
that are too far away (G039) THEN P6 - Myopia and Hypermetropia
\end{tabular}

\subsection{Case Examples}

An example of an analysis of the diagnosis of eye disease due to frequent use of computers using the Bayes theorem method is as follows:

a. Determine the Symptoms Experienced by the Patient

Suppose a patient chooses some of the symptoms of the disease he is experiencing, namely:

G001 : Vision begins to blur (Symptom Probability Score $=1.0$ )

G002: Eyes are sensitive to light (Symptom Probability Score $=0.9$ )

G007 : Headache Feels (Probability Score of Symptoms $=0.9$ )

b. Performing the process of calculating the probability value of symptoms against disease

After knowing the symptoms experienced by the patient, the next step is to calculate the probability of the symptoms to the disease.

1). Case Calculation Process for Diseases Blurred Vision (Cataract), Disease Probability Value = 1.0

- Symptoms Experienced = G001

$$
\begin{aligned}
\mathrm{P}(\mathrm{P} 1 \mid \mathrm{G} 001) & =\frac{\mathrm{P}(\mathrm{G} 001 \mid \mathrm{P} 1)^{*} \mathrm{p}(\mathrm{P} 1)}{\mathrm{P}(\mathrm{G} 001 \mid \mathrm{P} 1)^{*} \mathrm{p}(\mathrm{P} 1)+\mathrm{P}(\mathrm{G} 001 \mid \mathrm{P} 2)^{*} \mathrm{p}(\mathrm{P} 2)+\mathrm{P}(\mathrm{G} 001 \mid \mathrm{P} 3)^{*} \mathrm{p}(\mathrm{P} 3)} \\
& =\frac{\mathrm{P}(\mathrm{G} 001 \mid \mathrm{P} 1)^{*} \mathrm{p}(\mathrm{P} 1)}{+\mathrm{P}(\mathrm{G} 001 \mid \mathrm{P} 4)^{*} \mathrm{p}(\mathrm{P} 4)+\mathrm{P}(\mathrm{G} 001 \mid \mathrm{P} 5)^{*} \mathrm{p}(\mathrm{P} 5)+\mathrm{P}(\mathrm{G} 001 \mid \mathrm{P} 6)^{*} \mathrm{p}(\mathrm{P} 6)} \\
\mathrm{P}(\mathrm{P} 1 \mid \mathrm{G} 001) & =\frac{1.0 * 1.0}{1.0 * 1.0+0 * 0.9+0^{*} 1.0+0 * 0.8+0 * 0.9+0^{*} 1.0}=\frac{1}{1+0+0+0+0+0}=\frac{1}{1}=\mathbf{1}
\end{aligned}
$$

- Symptoms Experienced $=$ G002

$$
\begin{aligned}
\mathrm{P}(\mathrm{P} 1 \mid \mathrm{G} 002) & =\frac{\mathrm{P}(\mathrm{G} 002 \mid \mathrm{P} 1)^{*} \mathrm{p}(\mathrm{P} 1)}{\mathrm{P}(\mathrm{G} 002 \mid \mathrm{P} 1) * \mathrm{p}(\mathrm{P} 1)+\mathrm{P}(\mathrm{G} 002 \mid \mathrm{P} 2)^{*} \mathrm{p}(\mathrm{P} 2)+\mathrm{P}(\mathrm{G} 002 \mid \mathrm{P} 3)^{*} \mathrm{p}(\mathrm{P} 3)} \\
& =\frac{\mathrm{P}(\mathrm{G} 002 \mid \mathrm{P} 1)^{*} \mathrm{p}(\mathrm{P} 1)}{+\mathrm{P}(\mathrm{G} 002 \mid \mathrm{P} 4)^{*} \mathrm{p}(\mathrm{P} 4)+\mathrm{P}(\mathrm{G} 002 \mid \mathrm{P} 5)^{*} \mathrm{p}(\mathrm{P} 5)+\mathrm{P}(\mathrm{G} 002 \mid \mathrm{P} 6) * \mathrm{p}(\mathrm{P} 6)} \\
\mathrm{P}(\mathrm{P} 1 \mid \mathrm{G} 002) & =\frac{0.9 * 1.0}{0.9 * 1.0+0 * 0.9+0 * 1.0+0 * 0.8+0^{*} 0.9+0^{*} 1.0}=\frac{0.9}{0.9+0+0+0+0+0}=\frac{0.9}{0.9}=\mathbf{1}
\end{aligned}
$$

- Symptoms Experienced $=$ G007

$$
\begin{aligned}
\mathrm{P}(\mathrm{P} 1 \mid \mathrm{G} 007) & =\frac{\mathrm{P}(\mathrm{G} 007 \mid \mathrm{P} 1)^{*} \mathrm{p}(\mathrm{P} 1)}{\mathrm{P}(\mathrm{G} 007 \mid \mathrm{P} 1)^{*} \mathrm{p}(\mathrm{P} 1)+\mathrm{P}(\mathrm{G} 007 \mid \mathrm{P} 2)^{*} \mathrm{p}(\mathrm{P} 2)+\mathrm{P}(\mathrm{G} 007 \mid \mathrm{P} 3)^{*} \mathrm{p}(\mathrm{P} 3)} \\
& =\frac{\mathrm{P}(\mathrm{G} 007 \mid \mathrm{P} 1)^{*} \mathrm{p}(\mathrm{P} 1)}{+\mathrm{P}(\mathrm{G} 007 \mid \mathrm{P} 4)^{*} \mathrm{p}(\mathrm{P} 4)+\mathrm{P}(\mathrm{G} 007 \mid \mathrm{P} 5)^{*} \mathrm{p}(\mathrm{P} 5)+\mathrm{P}(\mathrm{G} 007 \mid \mathrm{P} 6)^{*} \mathrm{p}(\mathrm{P} 6)} \\
\mathrm{P}(\mathrm{P} 1 \mid \mathrm{G} 007) & =\frac{0}{0 * 1.0+0.7 * 0.9+0^{*} 1.0+0 * 0.8+0 * 0.9+0^{*} 1.0}=\frac{0}{0+0.63+0+0+0+0}=\frac{0}{0.63}=\mathbf{0}
\end{aligned}
$$

2). Case Calculation Process for Double Visible Vision Disease (Diplopia), Disease Probability Value $=0.9$

- Symptoms Experienced = G001

$$
\begin{aligned}
\mathrm{P}(\mathrm{P} 2 \mid \mathrm{G} 001) & =\frac{\mathrm{P}(\mathrm{G} 001 \mid \mathrm{P} 2)^{*} \mathrm{p}(\mathrm{P} 2)}{\mathrm{P}(\mathrm{G} 001 \mid \mathrm{P} 1)^{*} \mathrm{p}(\mathrm{P} 2)+\mathrm{P}(\mathrm{G} 001 \mid \mathrm{P} 2)^{*} \mathrm{p}(\mathrm{P} 2)+\mathrm{P}(\mathrm{G} 001 \mid \mathrm{P} 3)^{*} \mathrm{p}(\mathrm{P} 3)} \\
& =\frac{\mathrm{P}(\mathrm{G} 001 \mid \mathrm{P} 2)^{*} \mathrm{p}(\mathrm{P} 2)}{+\mathrm{P}(\mathrm{G} 001 \mid \mathrm{P} 4)^{*} \mathrm{p}(\mathrm{P} 4)+\mathrm{P}(\mathrm{G} 001 \mid \mathrm{P} 5)^{*} \mathrm{p}(\mathrm{P} 5)+\mathrm{P}(\mathrm{G} 001 \mid \mathrm{P} 6)^{*} \mathrm{p}(\mathrm{P} 6)} \\
\mathrm{P}(\mathrm{P} 1 \mid \mathrm{G} 001) & =\frac{0 * 0.9}{1.0 * 1.0+0^{*} 0.9+0 * 1.0+0^{*} 0.8+0 * 0.9+0 * 1.0}=\frac{0}{1+0+0+0+0+0}=\frac{0}{1}=\mathbf{0}
\end{aligned}
$$


- Symptoms Experieced $=$ G002

$$
\begin{aligned}
\mathrm{P}(\mathrm{P} 2 \mid \mathrm{G} 002) & =\frac{\mathrm{P}(\mathrm{G} 002 \mid \mathrm{P} 2)^{*} \mathrm{p}(\mathrm{P} 2)}{\mathrm{P}(\mathrm{G} 002 \mid \mathrm{P} 1)^{*} \mathrm{p}(\mathrm{P} 1)+\mathrm{P}(\mathrm{G} 002 \mid \mathrm{P} 2)^{*} \mathrm{p}(\mathrm{P} 2)+\mathrm{P}(\mathrm{G} 002 \mid \mathrm{P} 3)^{*} \mathrm{p}(\mathrm{P} 3)} \\
& =\frac{\mathrm{P}(\mathrm{G} 002 \mid \mathrm{P} 2)^{*} \mathrm{p}(\mathrm{P} 2)}{+\mathrm{P}(\mathrm{G} 002 \mid \mathrm{P} 4)^{*} \mathrm{p}(\mathrm{P} 4)+\mathrm{P}(\mathrm{G} 002 \mid \mathrm{P} 5)^{*} \mathrm{p}(\mathrm{P} 5)+\mathrm{P}(\mathrm{G} 002 \mid \mathrm{P} 6)^{*} \mathrm{p}(\mathrm{P} 6)} \\
\mathrm{P}(\mathrm{P} 1 \mid \mathrm{G} 001) & =\frac{0}{0.9 * 1.0+0 * 0.9+0 * 1.0+0 * 0.8+0 * 0.9+0 * 1.0}=\frac{0}{0.9+0+0+0+0+0}=\frac{0}{0.9}=\mathbf{0}
\end{aligned}
$$

- Symptoms Experienced = G007

$$
\begin{aligned}
& \mathrm{P}(\mathrm{P} 2 \mid \mathrm{G} 007)=\frac{\mathrm{P}(\mathrm{G} 007 \mid \mathrm{P} 2)^{*} \mathrm{p}(\mathrm{P} 2)}{\mathrm{P}(\mathrm{G} 007 \mid \mathrm{P} 1)^{*} \mathrm{p}(\mathrm{P} 1)+\mathrm{P}(\mathrm{G} 007 \mid \mathrm{P} 2)^{*} \mathrm{p}(\mathrm{P} 2)+\mathrm{P}(\mathrm{G} 007 \mid \mathrm{P} 3)^{*} \mathrm{p}(\mathrm{P} 3)} \\
& =\frac{\mathrm{P}(\mathrm{G} 007 \mid \mathrm{P} 2)^{*} \mathrm{p}(\mathrm{P} 2)}{\left.+\mathrm{P}(\mathrm{G} 007 \mid \mathrm{P} 4)^{*} \mathrm{p}(\mathrm{P} 4)+\mathrm{P}(\mathrm{G} 007 \mid \mathrm{P} 5)\right)^{*} \mathrm{p}(\mathrm{P} 5)+\mathrm{P}(\mathrm{G} 007 \mid \mathrm{P} 6)^{*} \mathrm{p}(\mathrm{P} 6)} \\
& \mathrm{P}(\mathrm{P} 1 \mid \mathrm{G} 007)=\frac{0.7^{*} 0.9}{0^{*} 1.0+0.7^{*} 0.9+0^{*} 1.0+0^{*} 0.8+0^{*} 0.9+0^{*} 1.0}=\frac{0.63}{0+0.63+0+0+0+0}=\frac{0.63}{0.63}=\mathbf{1}
\end{aligned}
$$

c. Diagnostic Results

Based on the symptoms experienced by the patient, it can be concluded that the patient has the following diseases:

1). P1 | Weight $=2$, with the name of the disease, namely Blurred Vision (Cataract), with the percentage of disease as follows:

$\mathrm{P} 1=\frac{\text { Weight } \mathrm{X} 100 \%}{\text { Total Disease }}=\frac{2 \times 100}{6}=\frac{200}{6}=33.333 \%$

2). P2 | Weight =1, with the name of the disease, namely Double Visible Vision (Diplopia), with the percentage of disease as follows:

$$
\text { P2 }=\frac{\text { Weight } X 100 \%}{\text { Total Disease }}=\frac{1 \times 100}{6}=\frac{100}{6}=16.666 \%
$$

Based on the results of the diagnosis, it can be concluded that the user suffers from the disease "Blurred Vision (Cataract) with a confidence value of 33.333\%.

\section{Conclusion}

This expert system for diagnosing eye diseases due to frequent use of computers is designed using Unified Modeling Language (UML) modeling by using Use Case diagrams, Activity Diagrams and Class Diagrams and is built using the PHP programming language with MySQL database. The results of the application of the Bayes theorem method show that the vision becomes blurred (cataracts) with a percentage yield of $33.33 \%$ and the disease "Double Vision (Diplopia) with a percentage yield of $16.67 \%$.

\section{References}

Kurniawan, M. B. (2017). SISTEM PAKAR DIAGNOSIS TIPE GANGGUAN JIWA SKIZOFRENIA MENGGUNAKAN METODE TEOREMA BAYES. Universitas Mercu Buana Yogyakarta.

Murni, S., \& Riandari, F. (2018). Penerapan Metode Teorema Bayes Pada Sistem Pakar Untuk Mendiagnosa Penyakit Lambung. JURNAL TEKNOLOGI DAN ILMU KOMPUTER PRIMA (JUTIKOMP), 1(2), 166-172.

Priliandita, N. T. (2015). Analisis Faktor Yang Berhubungan Dengan Keluhan Computer Vision Syndrome Pada Operator Komputer Warung Internet Di Kelurahan Sumbersari Kabupaten Jember.

Qamaruzzaman, M. H. (2016). Sistem Pakar Untuk Mendiagnosa Penyakit Mata Pada Manusia Menggunakan Teorema Bayes. IJNS-Indonesian Journal on Networking and Security, 5(4).

Ramadhan, P. S. (2018). Sistem Pakar Pendiagnosaan Dermatitis Imun Menggunakan Teorema Bayes. InfoTekJar: Jurnal Nasional Informatika Dan Teknologi Jaringan, 3(1), 43-48.

Ramadhan, P. S., Kom, M., Pane, U. F. S., \& Kom, M. (2018). Mengenal Metode Sistem Pakar. Uwais Inspirasi Indonesia.

Sagat, N. A., \& Purnomo, A. S. (2021). Sistem Pakar Diagnosa Penyakit Mata Menggunakan Metode Teorema Bayes. Jurnal Pendidikan Dan Teknologi Indonesia, 1(8), 329-337.

Sihotang, H. T., Panggabean, E., \& Zebua, H. (2018). Sistem Pakar Mendiagnosa Penyakit Herpes Zoster Dengan 
Menggunakan Metode Teorema Bayes. Journal Of Informatic Pelita Nusantara, 3(1).

Siregar, E. T. (2017). Penerapan Teorema Bayes Pada Sistem Pakar Untuk Mengidentifikasi Penyakit Tumbuhan Padi. Seminar Nasional Informatika (SNIf), 1(1), 23-26.

Sulardi, N., \& Witanti, A. (2020). Sistem Pakar Untuk Diagnosis Penyakit Anemia Menggunakan Teorema Bayes. Jurnal Teknik Informatika (Jutif), 1(1), 19-24.

Syahputra, T., Dahria, M., \& Putri, P. D. (2017). Sistem Pakar Untuk Mendiagnosa Penyakit Anemia Dengan Menggunakan Metode Teorema Bayes. Jurnal SAINTIKOM Vol, 16(3), 284. 